\title{
Evaluation of Fungicides, Bio-agents and Botanicals against Rhizoctonia spp. Incitant of Sheath Blight of Rice
}

\author{
Punam N. Usendi*, G. K. Giri and Sumant H. Kabade \\ Department of Plant Pathology, Dr.Panjabrao Deshmukh Krishi Vidyapeeth, \\ Akola- 444104 (M.S.), India \\ *Corresponding author
}

\section{A B S T R A C T}

\section{Keywords \\ Sheath blight, Rice, Rhizoctonia, \\ Fungicides, Bio- agents botanicals \\ Article Info \\ Accepted: \\ 24 July 2020 \\ Available Online: \\ 10 August 2020}

\begin{abstract}
Sheath blight is a destructive disease in all rice crop growing areas of the world. The present investigation was carried out to test the efficacy of fungicides, botanicals and bioagents. Among fungicides tested Propiconazole 13\% + Difenoconazole 13.9\% SC, Propiconazole 25\% EC, Tebuconazole 50\% + Trifoxystrobin 25\% WG, Hexaconazole 5\% EC and Carbendazim 50\% WP completely inhibited the radial growth of $R$. solani. The fungicide Azoxystrobin (21.11\%) and Validamaycin (30.37\%) found least effective. In vitro studies revealed that, all the four bio-agents were effective against the pathogen. The order of per cent inhibition of the fungus are Trichoderma reesei $(73.04 \%)>$ Trichoderma asperellum $(71.38 \%)>$ Pseudomonas fluorescens $(64.44 \%)>$ Bacillus subtilis $(61.38 \%)$. Among six botanical extracts (10\%) evaluated against $R$. solani, complete inhibition of the fungal mycelium was observed in garlic bulb extract which was significantly superior to rest of the treatments.
\end{abstract}

\section{Introduction}

Rice is an important crop worldwide, serving as the staple food for half of humanity and additionally being used in industry and for animal feed. Rice is grown in various agroecological zones in tropical and subtropical areas, especially in Asia, the continent accounting for $90 \%$ of the world production (IRRI, 2015a). India is the world's second largest rice producer and consumer next to China. About 90 per cent of rice grown in the world is produced and consumed in Asian continent. The production of rice to be achieved by 2020 is $128 \mathrm{Mt}$ to feed the growing population in India. To meet the global demand, it is estimated that about 114 Mt of additional milled rice needs to be produced by 2035 with an increase of $26 \%$ in next 25 years (Anonymous, 2016). In Maharashtra, rice is cultivated on 15.13 lakh hectares in regions viz. Vidarbha (7.95 lakh ha.), Konkan (3.83 lakh ha.), Western Maharashtra (3.23 lakh ha.) and Marathwada (0.12 lakh ha.) with annual production of 41.71 lakh tones.

Rice production worldwide is affected by various biotic and abiotic stresses (Richa et al., 2016). Sheath blight of rice caused by a 
soil-borne fungal pathogen, Rhizoctonia solani (Kuhn) is a destructive disease in all crop growing areas of the world. Sheath blight of rice caused by Rhizoctonia solani is one of the major biotic constraints in India and reduce rice yield ranging from $20-50 \%$ depending on the severity of the disease and stages of infection. The disease has spread widely in terms of both occurrence and intensity over past 20 years.

\section{Materials and Methods}

\section{Isolation and pathogenicity}

Fresh samples of diseased leaves, showing sheath blight symptoms were brought to the laboratory in paper bags. These samples were washed with running tap water to remove inert material. Small bits of desired size were cut by taking care that each bit contained half infected and half healthy portion. Such bits were then disinfected with 0.1 per cent sodium hypo chloride solution for 1 minute followed by three washings in distilled sterile water to remove the traces of mercuric chloride. These bits were then placed on sterilized blotters for drying. Properly dried bits were transferred aseptically in sterilized Petri plates containing sterilized, solidified PDA medium. All the above operations were carried out in sterilized condition (under laminar air flow unit). Then plates were incubated at $27 \pm 2{ }^{\circ} \mathrm{C}$ for 10 days. The fungal growth, which developed around each bit, was then transferred to PDA medium slant for sub culturing. The isolated fungi were identified as Rhizoctonia on the basis of morphological characters and published literature.

The pathogenicity of the isolates was determined by injection method on 40-dayold susceptible rice cultivar Swarna. The culture with fungal mycelia (and sclerotia) was taken in a disposable syringe of $0.5 \mathrm{ml}$ capacity then placed in between the tillers in the central region of the hill, 5-10 $\mathrm{cm}$ above the water line. Care was taken that no air bubble was trapped in the suspension. Bigger wounds were avoided at the point of injection. Healthy uninoculated plants served as control. The pathogen was reisolated on the PDA medium from the symptomatic plants and microscopic observations made were found similar to that of the organism isolated from naturally diseased rice plants. Thus, the test pathogen was confirmed as Rhizoctonia solani and pathogenicity of Rhizoctonia solani was proved.

\section{In vitro evaluation of fungicides by poisoned food technique}

Poisoned food technique was used to evaluate the efficiency of seven fungicides against pathogens. Potato dextrose agar medium was prepared and distributed at the rate of $100 \mathrm{ml}$ in $250 \mathrm{ml}$ conical flask, autoclaved $1.05 \mathrm{~kg} / \mathrm{cm} 2$ for $15 \mathrm{~min}$. Then before solidification of media different fungicides with desired concentration were incorporated aseptically in different flasks.

These flasks shaken to facilitate uniform mixture of fungicides thoroughly and poured in Petri plate's $20 \mathrm{ml} /$ plate likewise three plates for each treatment were poured. One set of three plates was poured without any fungicides to serve as a control. After solidification of medium, the plates inoculated with seven days old pathogens separately. Five $\mathrm{mm}$ diameter mycelial disc selected from peripheral growth of the plate by sterilized cork borer were used for inoculating the plates by keeping one disc per plate in the centre in inverted position, so as to make the mycelial growth touch the surface of medium. The inoculated plates were incubated at room temperature for seven days. The colony diameter of the fungal pathogens on medium was recorded and percent 
inhibition in each treatment was calculated by using following formula (Vincent, 1927).

$$
\mathrm{PI}=\mathrm{x} 100 \quad \frac{\mathrm{C}-\mathrm{T}}{\mathrm{C}}
$$

Where,

$\mathrm{PI}=$ Percent Inhibition

$\mathrm{C}=$ Growth of fungi in control ( $\mathrm{mm}$ )

$\mathrm{T}=$ Growth of fungi in treatment $(\mathrm{mm})$

In vitro evaluation of botanicals by poisoned food technique

Aqueous leaf extracts of the test botanicals were obtained by grinding the washed rhizome and leaves (100 g) in mortal and pestle with equal volume $(100 \mathrm{ml})$ of sterilized distilled water. The macerate obtained was filtered through the folds of muslin cloth and the filtrate obtained formed $100 \%$ phytoextracts, which were evaluated by poisoned food method. Twenty $\mathrm{ml}$ of poisoned medium was poured into each stetrile petriplates. Five $\mathrm{mm}$ diameter mycelial disc selected from periphery of actively growing culture were cut out by sterilized cork borer were used for inoculating the plates by keeping one disc per plate in the centre in inverted position, so as to make the mycelial growth touch the surface of medium. of each agar plate. Control was also maintained by growing the pathogen on PDA plates. The inoculated plates were incubated at room temperature for seven days. The colony diameter of the fungal pathogens on medium was recorded and percent inhibition in each treatment was calculated by using above formula.

\section{In vitro evaluation of bio-agents by dual culture method}

The lawn culture of test fungi and bio-agents viz., Trichoderma asperellum and
Trichoderma reesei were prepared. Autoclaved, melted potato dextrose agar was poured in petri plates and allowed to solidify for obtaining leveled surface. The plates were inoculated with the culture of test fungi and bio-agents after solidification of media and then plates were incubated at room temperature for seven days.

Bacterial bio-agents, Bacillus subtilis and Pseudomonas fluorescens were prepared by inoculating a loopful culture in sterilized conical flask containing $100 \mathrm{ml}$ of nutrient broth. Broth culture was incubated at room temperature for three days. Five $\mathrm{mm}$ disc of one week old test fungus and bio-agent lawn culture was cut with the help of sterilized cork borer lifted and transferred in petri plates, containing autoclaved solidified PDA medium. In each petri plates, four discs of bio-agents were inoculated at four peripheral points of the plates and the test fungi was placed in the center of petri plates. In case of Pseudomonas fluorescens and Bacillus subtilis, a three days old culture was streaked around the disc of test fungus. The test fungi grown in same condition on potato dextrose agar without bio-agents served as control. All these plates were incubated at room temperature for seven days. After an expiry of seven days incubation period the mycelial inhibition was calculated as per formula mentioned in the poisoned food method.

\section{Results and Discussion}

\section{Efficacy of fungicides against Rhizoctonia solani}

Seven fungicides were tested in laboratory against Rhizoctonia solani for their efficacy against radial growth. Data presented in table 1 clearly showed that all the fungicides taken in this investigation were effective against $R$. solani and significantly inhibited the radial growth in vitro at different concentrations. 
Out of which Propiconazole 13\%+ Difenoconazole $13.9 \%$ SC, Propiconazole $25 \%$ EC, Tebuconazole $50 \%+$ Trifoxystrobin $25 \%$ WG, Hexaconazole 5\% EC and Carbendazim 50 WP completely inhibited the radial growth of the fungus at test concentrations on Potato dextrose agar medium. The fungicide Azoxystrobin and Validamaycin found least effective i.e., $21.11 \%$ and $30.37 \%$ respectively. Similar results were observed by Hunjan et al., (2011) also reported that fungicides viz., Trifoxystrobin + Tebuconazole and Propiconazole showed higher level of efficacy against Rhizoctonia solani. Subhash Chandra et al., (2016) reported that Propiconazole, Carbendazim and Hexaconazole completely inhibited the mycelial growth of Rhizoctonia solani followed by Validamaycin at different concentrations (Fig. 1).

Table.1 Efficacy of fungicides against Rhizoctonia solani

\begin{tabular}{|c|c|c|c|c|}
\hline $\begin{array}{l}\text { Sr. } \\
\text { No. }\end{array}$ & Fungicides & Conc. (\%) & $\begin{array}{c}\text { Mean colony diameter } \\
(\mathbf{m m}) *\end{array}$ & $\begin{array}{c}\text { Mycelial } \\
\text { inhibition (\%) }\end{array}$ \\
\hline 1 & $\begin{array}{l}\text { Propiconazole } 13 \% \text { + Difenconazole } \\
13.9 \% \text { SC }\end{array}$ & 0.1 & 0.00 & 100.0 \\
\hline 2 & Propiconazole $25 \%$ EC & 0.1 & 0.00 & 100.0 \\
\hline 3 & $\begin{array}{l}\text { Tebuconazole } 50 \%+\text { Trifloxystrobin } \\
25 \% \text { WG }\end{array}$ & 0.1 & 0.00 & 100.0 \\
\hline 4 & Azoxystrobin $23 \%$ SC & 0.1 & 71.00 & 21.11 \\
\hline 5 & Validamaycin 3\% L & 100 ppm & 63.00 & 30.00 \\
\hline 6 & Hexaconazole $5 \%$ EC & 0.2 & 0.00 & 100.0 \\
\hline 7 & Carbendazim $50 \mathrm{WP}$ & 0.2 & 0.00 & 100.0 \\
\hline \multirow[t]{4}{*}{8} & Control & - & 90.00 & \\
\hline & $\mathrm{F}$ ' test & - & Sig. & - \\
\hline & $\mathrm{SE}(\mathrm{m}) \pm$ & - & 0.45 & - \\
\hline & $\mathrm{CD}(\mathrm{P}=0.01)$ & - & 1.88 & \\
\hline
\end{tabular}

*Average of three replications

Table.2 Efficacy of bio-agents against Rhizoctonia solani

\begin{tabular}{|c|l|c|c|}
\hline Sr. No. & \multicolumn{1}{|c|}{ Bio-agents } & $\begin{array}{c}\text { Mean radial mycelial } \\
\text { growth }(\mathbf{m m})\end{array}$ & $\begin{array}{c}\text { Per cent mycelial } \\
\text { inhibition }(\mathbf{\%})\end{array}$ \\
\hline 1 & Trichoderma asperellum & 25.75 & 71.38 \\
\hline 2 & Trichoderma reesei & 24.25 & 73.05 \\
\hline 3 & Pseudomonas fluorescens & 32.00 & 64.44 \\
\hline 4 & Bacillus subtilis & 34.75 & 61.38 \\
\hline 5 & Control & 90.00 & - \\
\hline & F' test & Sig. & - \\
\hline & SE $(m) \pm$ & 1.24 & - \\
\hline & CD $(\mathrm{P}=0.01)$ & 3.66 & - \\
\hline
\end{tabular}

*Average of four replications 
Table.3 Efficacy of botanicals against Rhizoctonia solani

\begin{tabular}{|c|c|c|c|c|}
\hline Sr. No. & Botanicals & $\begin{array}{c}\text { Conc. } \\
(\%)\end{array}$ & $\begin{array}{c}\text { Mean radial } \\
\text { Mycelial growth }(\mathrm{mm}) *\end{array}$ & $\begin{array}{c}\text { Mycelial } \\
\text { inhibition (\%) }\end{array}$ \\
\hline 1 & $\begin{array}{l}\text { Tulsi leaves extract } \\
\text { (Ocimum sanctum) }\end{array}$ & 10.00 & 26.66 & 70.37 \\
\hline 2 & $\begin{array}{l}\text { Neem leaves extract } \\
\text { (Azadiracta indica) }\end{array}$ & 10.00 & 28.00 & 68.88 \\
\hline 3 & $\begin{array}{l}\text { Aloe vera leaves extract } \\
\text { (Aloe vera) }\end{array}$ & 10.00 & 28.66 & 68.15 \\
\hline 4 & $\begin{array}{l}\text { Karanj leaves extract } \\
\text { (Pongamia pinnata) }\end{array}$ & 10.00 & 32.00 & 64.44 \\
\hline 5 & $\begin{array}{l}\text { Garlic bulb extract } \\
\text { (Allium sativum) }\end{array}$ & 10.00 & 0.00 & 100.0 \\
\hline 6 & $\begin{array}{l}\text { Lemon grass extract } \\
\text { (Cymbopogon flexuosus) }\end{array}$ & 10.00 & 28.33 & 68.52 \\
\hline \multirow[t]{4}{*}{7} & Control & - & 90.0 & \\
\hline & $F^{\prime}$ test & - & Sig. & - \\
\hline & $\mathrm{SE}(\mathrm{m}) \pm$ & - & 0.81 & - \\
\hline & $\mathrm{CD}(\mathrm{P}=0.01)$ & & 3.43 & \\
\hline
\end{tabular}

*Average of three replications

Fig.1 Efficacy of fungicides against Rhizoctonia solani

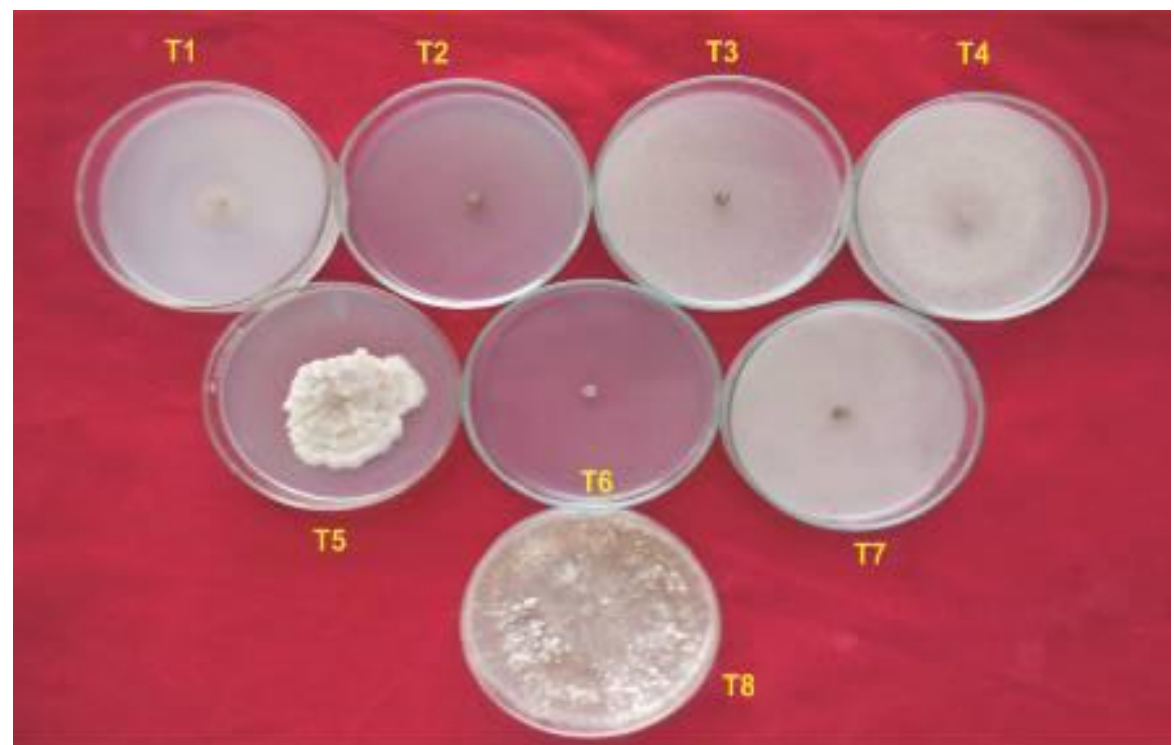

T1- Propiconazole+Difenconazole (0.1\%) T5- Validamaycin (100 ppm)

T2- Propiconazole $(0.1 \%) \quad$ T6- Hexazonazole $(0.2 \%)$

T3- Tebuconazole+Trifoxystrobin $(0.1 \%) \quad$ T7-Carbendazim $(0.2 \%)$

T4- Azoxystrobin $(0.1 \%) \quad$ T8- Control 
Fig.2 Efficacy of bio-agents against Rhizoctonia solani

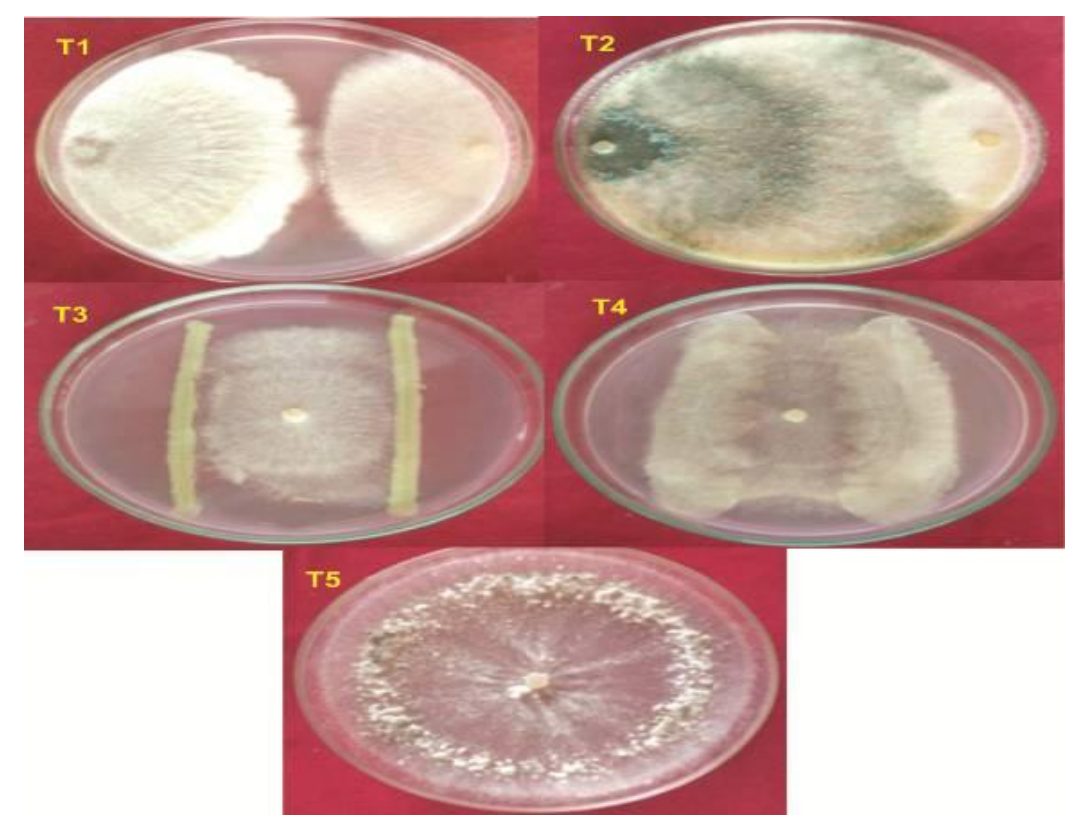

\section{T1- Trichoderma asperellum T3-Pseudomonas fluorescens}

T2- Trichoderma reesei T4-Bacillus subtilis T5- Control

Fig.3 Efficacy of botanicals against Rhizoctonia solani

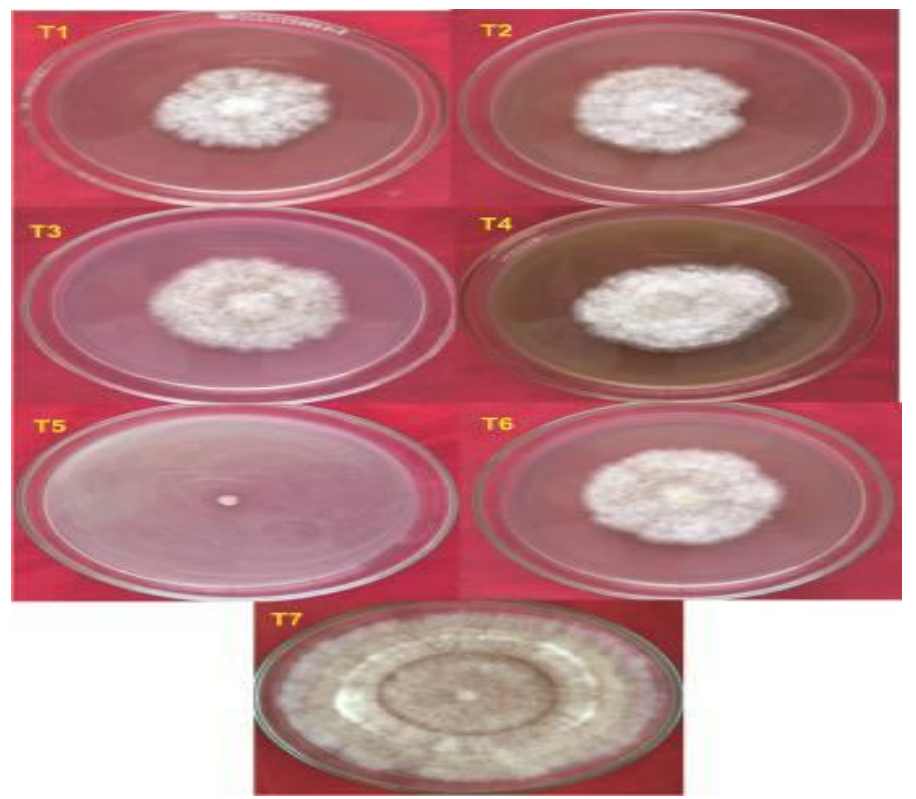

T1- Tulsi leaves (Ocimum sanctum) T5- Garlic bulb (Allium sativum)

T2- Neem leaves (Azadiracta indica) T6- Lemon grass (Cymbopogon flexuosus)

T3- Aloe vera leaves (Aloe vera) T7- Control

T4- Karanj leaves (Pongamia pinnata) 
Efficacy of bio-agents against Rhizoctonia solani

Bio-agents were evaluated for their inhibiting effect against the pathogen in vitro by dual culture technique as described in "Material and Methods". The results of average diameter of fungal colony incubated at $27 \pm$ $1^{0} \mathrm{c}$ after 7 days are presented in table 2 , revealed that all the bioagents suppressed colony growth of $R$. solani. The order of percent inhibition of the fungus as follows, Trichoderma reesei $(73.04 \%)>$ Trichoderma asperellum $(71.38 \%)>$ Pseudomonas fluorescens $(64.44 \%)>$ Bacillus subtilis $(61.38 \%)$. Result on same line observed by Reddy et al. (2010) reported that Pseudomonas fluorescens (P.f.003) strain effectively controlled the pathogen Rhizoctonia solani by $77.78 \%$ and (P.f. 008) by $20 \%$ causing sheath blight of rice (Fig. 2).

\section{Efficacy of botanicals against Rhizoctonia solani}

The effect of plant extracts of six plant species was studied against $R$. solani to test their antifungal properties. All the plant extracts were tested at 10 per cent concentration by poisoned food technique. All the plant extracts under study exhibited antifungal properties against $R$. solani. The data on the effect of different plant extracts on mycelial growth of the pathogen are presented in table 3 (Fig. 3).

The complete inhibition of the fungal mycelium (100.0\%) was observed in garlic bulb extract which was significantly superior to rest of the treatments. It was followed by tulsi leaves $(70.37 \%)$, neem leaves $(68.88 \%)$, lemon grass leaves $(68.52 \%)$, aloe vera leaves $(68.15 \%)$ and karanj leaves (64.14\%) respectively. The present results of botanicals similar with Koma et al., (2014) who reported complete mycelial inhibition of Rhizoctonia solani with Garlic bulb extract in groundnut followed by Neem leaves $(60.37 \%)$.

\section{References}

Anonymous. (2016). Krishi Darshika I.G.K.V. Raipur (C.G.) pp. 4-5.

Hunjan, M. S., Lore J. S., Pannu P. S. and Thind T. S. 2011. Performance of some new fungicides against sheath blight and brown spot of rice. Pl. Dis. Res., 26(1): 61-67.

IRRI (2015a). World Rice Statistics in (2013). Available at: http://ricestat.irri.org

Koma B., Dewangan P., Baghel S., Dantre R. K. and Verma K. P. 2014. Efficacy of plant leaf extracts on mycelia growth and sclerotial production of Rhizoctonia solani causing web blight of groundnut. International Journal of Plant Protection, Vol.7. ISSN-0976-6855.

Reddy P. B., Rani J., Reddy M. S. and Kumar K. V. K. 2010. In-vitro antagonistic potential of pseudomonas fluorescens isolates and there metabolites against rice sheath blight pathogen, Rhizoctonia solani. IJABPT, Vol. I. ISSN: 09764550.

Richa, K., Tiwari I. M., Kumari M., Devanna B. N., Sonah H., Kumar A., Nagar R., Sharma V., Botel J. R. and Sharma T. R. 2016. Functional Characterization of Novel Chitinase Genes Present in the Sheath Blight Resistance QTL: qSBR11-1in Rice Line Tetep. Frontiers in Plant Science, 7:1-10.

Subhash, C., Singh H.K., Kumar P. and Yadav Y. 2016. Screening of Rice (Oryza sativa L.) Genotypes for Sheath Blight (Rhizoctonia solani) in changing Climate Scenario. J. Agri. Sear, 3(2):130-132.

Vincent, J. M. 1927. Distoration of fungal hyphae in presence of certain inhibitors. Nature, 159:850. 


\section{How to cite this article:}

Punam N. Usendi, G. K. Giri and Sumant H. Kabade. 2020. Evaluation of Fungicides, Bioagents and Botanicals against Rhizoctonia spp. Incitant of Sheath Blight of Rice. Int.J.Curr.Microbiol.App.Sci. 9(08): 3039-3046. doi: https://doi.org/10.20546/ijcmas.2020.908.343 